\title{
Analysis of compressive strength of occlusal splints manufactured with three liquid resins at three angles of orientation on 3D printer
}

Análise de resistência a compressão de placas oclusais fabricadas por três resinas líquidas, confeccionadas em impressora 3D em três orientações de angulação

Análisis de resistencia a la compresión de férulas oclusales de tres resinas líquidas, realizadas en una impresora 3D en tres orientaciones de angulación

Selem Alvarenga Vilela

ORCID: https://orcid.org/0000-0002-9265-9974

Faculdade São Leopoldo Mandic, Brasil E-mail: selemalvarenga@hotmail.com

Amanda Gonçalves Franco

ORCID: https://orcid.org/0000-0003-0983-7539

Universidade de Itaúna, Brasil

E-mail: amandagfranco38@gmail.com

Aline Batista Gonçalves Franco

ORCID: https://orcid.org/0000-0002-8793-0459

Faculdade São Leopoldo Mandic, Brasil

E-mail: alinebgfranco@yahoo.com

Geraldo Alberto Pinheiro de Carvalho

ORCID: https://orcid.org/0000-0002-6279-3558

Faculdade São Leopoldo Mandic, Brasil E-mail: cdgeraldo@yahoo.com.br

Sérgio Candido Dias

ORCID: https://orcid.org/0000-0003-2570-2167

Faculdade São Leopoldo Mandic, Brasil E-mail: cdsergiodias@gmail.com

Silvio Mecca Junior

ORCID: https://orcid.org/0000-0003-2567-3976 Faculdade São Leopoldo Mandic, Brasil E-mail: silviomecca@gmail.com

Fabiano Perez

ORCID: https://orcid.org/0000-0002-3399-1002

Faculdade São Leopoldo Mandic, Brasil

E-mail: fabiano.perez.odonto@gmail.com

Elimario Venturin Ramos

ORCID: https://orcid.org/0000-0001-7325-4093 Faculdade São Leopoldo Mandic, Brasil E-mail: drelimario@gmail.com

Francisco Fernando Massola Filho ORCID: https://orcid.org/0000-0002-1726-8252

Faculdade São Leopoldo Mandic, Brasil E-mail: drfranciscomfilho@gmail.com

Caio Marques Martins

ORCID: https://orcid.org/0000-0002-6236-8973 Faculdade São Leopoldo Mandic, Brasil E-mail: drcaiomartins@uol.com.br

\begin{abstract}
The aim of this study is to analyze the compressive strength of occlusal splints manufactured with three different liquid resins in a 3D printer and in three angles of orientation. The resins used here are $(n=12)$ : Resilab Clear (Wilcos do Brasil, Petrópolis, RJ, Brazil), Prizma Smart Print Bio (Makertech Labs, Tatuí, SP, Brazil), and Cosmos Splint (Yller Biomateriais, Pelotas, RS, Brazil); each resin group are divided into three subgroups according to orientation of manufacture: 0,45 and 90 degrees. A dental manikin was scanned and the file was used to manufacture a steel hemiarch model. This model was used to design the occlusal splints and as a basis for the tests. The splints were designed with flat occlusal surface and minimum thickness of $2 \mathrm{~mm}$. The compressive test was performed with constant force of $200 \mathrm{~N}$, velocity of $0.5 \mathrm{~mm} / \mathrm{min}$, along the entire occlusal surface until fracture. Results show no difference between the resins, regardless of orientation of manufacture. The orientation showed no intragroup effect for resins Prizma Smart Print Bio and Resilab Clear; the resin
\end{abstract}


Cosmos showed larger compressive strength for the samples manufactured at 45 degrees than at 0 degree. The 90 -degree samples were intermediary and showed no difference from other angles. This study shows that the three resins had similar behavior in terms of compressive strength, except for the intragroup effect of orientation of Cosmos Splint resin, where plates manufactured at 0 degree performed worse than those at 45 degrees.

Keywords: Occlusal splints; Three-dimensional printing; Computer aided design.

\section{Resumo}

O objetivo deste trabalho foi analisar a resistência de placas oclusais produzidas em impressora 3D, fabricadas por três resinas líquidas e feitas em três orientações de confecção. As resinas foram dividas em três grupos $(\mathrm{n}=12)$ : Resilab Clear (Wilcos do Brasil, Petrópolis, RJ, Brasil), Prizma Smart Print Bio (Makertech Labs, Tatuí, SP, Brasil), Cosmos Splint (Yller Biomateriais, Pelotas, RS, Brasil); cada uma com subgrupos para cada angulação: 0, 45 e 90 graus. Um manequim de dentística foi escaneado e o arquivo utilizado para confeccionar um modelo de aço em hemiarco. Este modelo foi utilizado para desenhar as placas oclusais e foi base para os testes. As placas foram confeccionadas com superfície oclusal plana e espessura mínima de $2 \mathrm{~mm}$. O teste de compressão foi realizado com força constante de $200 \mathrm{~N}$, velocidade de 0,5 $\mathrm{mm} / \mathrm{min}$, em toda superfície oclusal das placas até a fratura. Os resultados não mostraram diferença entre as três resinas, independente da orientação de angulação. Quando investigado o efeito da orientação intragrupo, com as resinas Prizma Smart Print Bio e Resilab Clear não houve diferença. Já com a resina Cosmos, em 45 graus, foram obtidos valores de resistência maiores que na orientação de 0 grau. Já em 90 graus, foi intermediária, não diferindo das demais orientações. Conclui-se que as três resinas se comportaram da mesma forma em relação à resistência a compressão, exceto ao analisar o efeito intragrupo de orientação na resina Cosmos Splint, onde placas confeccionadas em 0 grau tiveram comportamento inferior em relação angulação de 45 graus.

Palavras-chave: Placas oclusais; Impressão tridimensional; Desenho assistido por computador.

\section{Resumen}

El objetivo de este trabajo fue analizar la resistencia de férulas oclusales producidas en una impresora 3D, fabricadas con tres resinas líquidas y realizadas en tres orientaciones de fabricación. Las resinas se dividieron en tres grupos ( $\mathrm{n}=12$ ): Resilab Clear (Wilcos do Brasil, Petrópolis, RJ, Brasil), Prizma Smart Print Bio (Makertech Labs, Tatuí, SP, Brasil), Cosmos Splint (Yller Biomaterials, Pelotas, RS, Brasil); cada uno con subgrupos para cada ángulo: 0, 45 y 90 grados. Se escaneó un maniquí dental y se usó el archivo para hacer un modelo de acero de hemiarca. Este modelo se utilizó para diseñar las férulas oclusales y fue la base para las pruebas. Las placas se realizaron con una superficie oclusal plana y un espesor mínimo de $2 \mathrm{~mm}$. La prueba de compresión se realizó con una fuerza constante de $200 \mathrm{~N}$, velocidad de $0,5 \mathrm{~mm} / \mathrm{min}$, en toda la superficie oclusal de las placas hasta la fractura. Los resultados no mostraron diferencias entre las tres resinas, independientemente de la orientación de la angulación. Al investigar el efecto de la orientación intragrupo, con las resinas Prizma Smart Print Bio y Resilab Clear no hubo diferencia. Con la resina Cosmos, a 45 grados, se obtuvieron mayores valores de resistencia que en la orientación de 0 grados. A 90 grados, era intermedia, sin diferenciarse de las otras orientaciones. Se concluye que las tres resinas se comportaron de igual forma en relación a la resistencia a la compresión, excepto al analizar el efecto intragrupo de orientación en la resina Cosmos Splint, donde las placas elaboradas a 0 grados tuvieron un comportamiento menor en relación a los 45 grados.

Palavras clave: Férulas oclusales; Impresión tridimensional; Diseño asistido por ordenador.

\section{Introduction}

The occlusal splint is a removable device used to improve the temporomandibular joint stability and enable a functional occlusion, which reorganizes the neuromuscular reflex activity (Maia, 2014). These devices are also used to protect the teeth of patients with bruxism from wear and excessive occlusal forces, and to minimize the symptoms of temporomandibular disorders. They can also be used to test a new occlusal dimension of patients in need of extensive prosthetic treatment. (Reymus \& Stawaczyk, 2020)

Traditional manufacturing techniques of occlusal splints require several laboratory steps, which increases the odds of errors and distortions. In the last years, new technologies enabled the manufacturing of digitized occlusal splints that improve and simplify treatment (Vasques, 2018). This manufacturing process can either be subtractive, with the use of milling procedure, or additive, with the use of 3D printing. (Reymus et al., 2020).

The additive method of manufacturing was first described in 2013 and used stereolithography (SLA). Nowadays, SLA and DLP (Digital Light Processing) are commonly used technologies in the manufacturing of occlusal devices and both techniques use liquid resin immediately polymerized with laser (SLA) or light beam in wide areas (DLP) (Reymus \& Stawarczyk, 2020).

In $3 \mathrm{D}$ printing, the angle of orientation may affect the reproducibility of the test specimens in terms of roughness and 
strength (Unkovskiy et al., 2018).

Regardless of the manufacturing process, the material used in the occlusal device must meet the mechanical requirements to allow its clinical use and must be resistant to occlusal forces of up to $770 \mathrm{~N}$ and to the impact of clenching and grinding of teeth. This study aims to analyze, through compressive tests, the resistance of occlusal splints manufactured in a MoonRay 3D printer (SprintRay Inc. Los Angeles-CA, USA) with DLP technology, using three liquid resins: Resilab Clear (Wilcos do Brasil indústria e comércio LTDA Petrópolis-RJ, Brazil), Prizma Smart Print Bio (Makertech Labs- Resinas para impressora 3D BF Tecnologia 3D LTDA; Tatuí - SP, Brazil), Cosmos Splint (Yller Biomateriais; Pelotas- RS, Brazil) and three angle of orientations: 0, 45 and 90 degrees.

\section{Methods}

Samples calculation was run on G*Power 3.1.9.4. The groups were defined with 12 samples for each resin type and 4 samples for each angle. Therefore, each subgroup was composed of 4 test specimens for each angle, totaling 36 occlusal splints.

The test specimens were manufactured using DLP technology in a MoonRay 3D printer (SprintRay Inc. Los Angeles-CA, USA) with photopolymerized resins divided into three groups according to resin type: Resilab Clear (Wilcos do Brasil indústria e comércio LTDA Petrópolis-RJ, Brazil); Prizma Smart Print Bio (Makertech Labs- Resinas para impressora 3D BF Tecnologia 3D LTDA; Tatuí-SP, Brazil); and Cosmos Splint (Yller Biomateriais; Pelotas- RS, Brazil).

For the production of the test specimens, a dental manikin (DENT-ART Materiais Didáticos Odontológicos Ltda. São Paulo-SP, Brazil) was scanned on a bench scanner Ceramill MAP 400+ (Amann Girrbach Brasil LTDA, Curitiba-PR, Brazil) to generate an STL file. The file was used as the basis to produce a 2D model in steel (Figure 1), which was then machined on a DCM 620-5F (Indústrias ROMI S.A. Santa Bárbara do Oeste-SP, Brazil). The model was tempered with 46 HRC and scanned with the bench scanner Ceramill MAP 400+ (Amann Girrbach Brasil LTDA, Curitiba-PR, Brazil) to serve as the model for the design and manufacture of the occlusal splints and as a basis for the compressive test of the test specimens.

Figure 1 - Steel model.

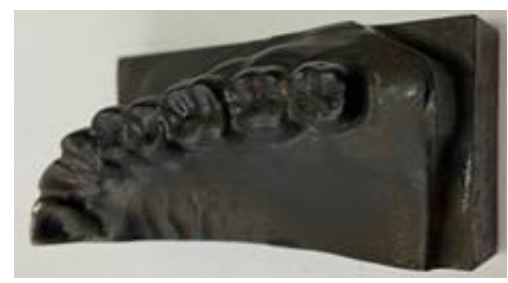

Source: Authors.

The test specimens were designed as hemiarches; the splint's occlusal surface is flat and encompasses the region from the upper right second molar to the upper right first premolar. The splints measure $35 \mathrm{~mm}$ X $12 \mathrm{~mm}$ X 5mm and have minimum thickness of $2 \mathrm{~mm}$, considering the longest cuspid (Vasques, 2018).

The test specimens were manufactured in three different angles in the 3D printer; 0 degree (4 test specimens; Figure 2), 45 degrees (4 test specimens; Figure 3), and 90 degrees (4 test specimens; Figure 4). 
Figure 2- Plate manufactured at 0 degree.

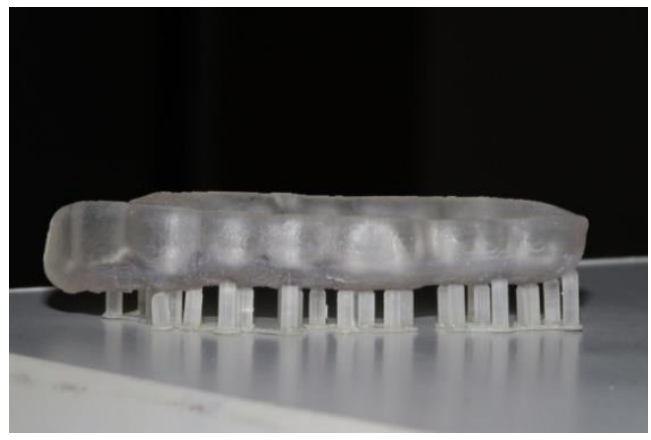

Source: Authors.

Figure 3 - Plate manufactured at 45 degrees.

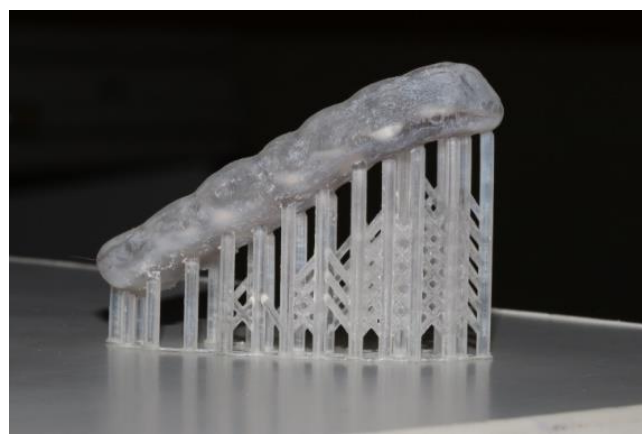

Source: Authors.

Figure 4 - Plate manufactured at 90 degrees.

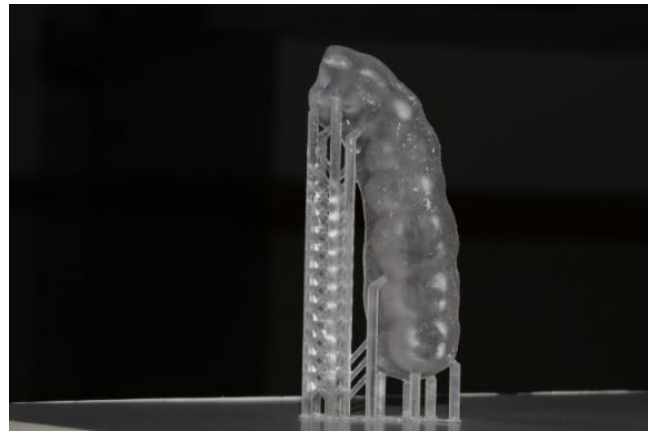

Source: Authors.

After printing, the excess resin was removed with 2 isopropyl alcohol (Isopropanol, Votorantim, São Paulo - Brazil) baths (Berli et al., 2020): the first bath for 3 minutes, followed by a second bath for 2 minutes, replacing the alcohol between procedures. The splints were dried and taken to the light chamber, Photopolymerizer LabFlo UV (Labflo São Paulo-SP, Brazil) oven for 12 minutes according to the manufacturer's recommendations. Supports were removed using an engine (straight part) and milling machine (Maxicut Black, series XXBL 105, Trihawk, Morrisburg, Ontario, Canada) (Vasques, 2018).

A compression bar was manufactured with the same dimensions of the occlusal splints ( $35 \mathrm{~mm} \times 12 \mathrm{~mm} \times 5 \mathrm{~mm}) \mathrm{so}$ that the compression was applied along the test specimen. The compressive strength of the materials used in the splints was analyzed by submitting all samples to constant strength until fracture (Figure 5) (Ribeiro et al., 2014). The test was performed on a universal testing machine EMIC DL 2000 (Instron Brasil Equipamentos científicos Ltda., São José dos Pinhais-PR, Brazil) (Wendler et al., 
2016), applying $200 \mathrm{~N}$ at $0.5 \mathrm{~mm} / \mathrm{min}$, as per the protocol in De Carvalho et al. (2017).

Figure 5 - Compressive test of occlusal splint over steel model.

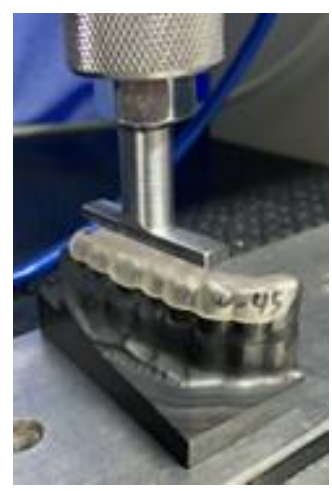

Source: Authors.

The distribution of compressive strength values did not follow the normal distribution. Hence, data were compared using Kruskal-Wallis and Dunn's non-parametric tests. All statistical calculations were run on SPSS 23 (SPSS Inc., Chicago, IL, USA), with $5 \%$ of significance.

\section{Results}

The Kruskal-Wallis' test showed no significant difference between resins Resilab Clear (Wilcos), Prizma Smart Print Bio (Makertech Labs) and Cosmos Splint (Yller) used in the occlusal splints, regardless of angle of orientation, as seen in Table 1 and Graph 1. 
Table 1 - Averages, standard deviations, medians and minimum and maximum values of compressive strength (N) of the resins used in the Michigan plates, according to angle of orientation.

\begin{tabular}{|c|c|c|c|c|}
\hline \multirow[b]{2}{*}{ Angle of orientation } & \multicolumn{3}{|c|}{ Resin used in the Michigan plates } & \multirow[b]{2}{*}{ p-value } \\
\hline & $\begin{array}{c}\text { Prizma Smart Print Bio } \\
\text { Markertch }\end{array}$ & $\begin{array}{l}\text { Resilab Clear } \\
\text { Wilcos }\end{array}$ & $\begin{array}{l}\text { Cosmos Splint } \\
\text { Yller }\end{array}$ & \\
\hline 0 degree & $\begin{array}{c}3772.51^{\text {Aa }}(3827.30) \\
\text { Med: } 2256.00 \\
\text { Min: } 1126.94 \\
\text { Max: } 9451.09\end{array}$ & $\begin{array}{c}3744.32 \text { Aa }(3084.80) \\
\text { Med: } 2553.07 \\
\text { Min: } 1580.12 \\
\text { Max: } 8291.03\end{array}$ & $\begin{array}{c}1496.25^{\mathrm{Ab}}(45.99) \\
\text { Med: } 1504.71 \\
\text { Min: } 1433.52 \\
\text { Max: } 1542.06\end{array}$ & 0.105 \\
\hline 45 degrees & $\begin{array}{c}3594.38^{\mathrm{Aa}}(746.73) \\
\text { Med: } 3695.86 \\
\text { Min: } 2661.25 \\
\text { Max: } 4324.53\end{array}$ & $\begin{array}{c}6512.87^{\text {Aa }}(3472.21) \\
\text { Med: } 6877.24 \\
\text { Min: } 2553.42 \\
\text { Max: } 9743.58\end{array}$ & $\begin{array}{c}6722.72 \text { Aa }(419.64) \\
\text { Med: } 6908.96 \\
\text { Min: } 6097.75 \\
\text { Max: } 6975.20\end{array}$ & 0.116 \\
\hline 90 degree & $\begin{array}{c}4416.50 \text { Aa }(1026.78) \\
\text { Med: } 4355.54 \\
\text { Min: } 3503.46 \\
\text { Max: } 5451.47\end{array}$ & $\begin{array}{c}3278.99 \text { Aa }(345.88) \\
\text { Med: } 3386.12 \\
\text { Min: } 2802.91 \\
\text { Max: } 3540.81\end{array}$ & $\begin{array}{c}4781.05 \text { Aab }(1573.78) \\
\text { Med: } 4839.02 \\
\text { Min: } 2834.62 \\
\text { Max: } 6611.54\end{array}$ & 0.174 \\
\hline p-value & 0.292 & 0.246 & 0.010 & - \\
\hline
\end{tabular}

Caption: Standard deviation in brackets. Med = median; Min = minimum value; Max = maximum value. Source: Authors.

Graph 1 - Bar chart of compressive strength $(\mathrm{N})$ of the resins used in the manufacturing of the Michigan plates, according to angle of manufacture orientation.

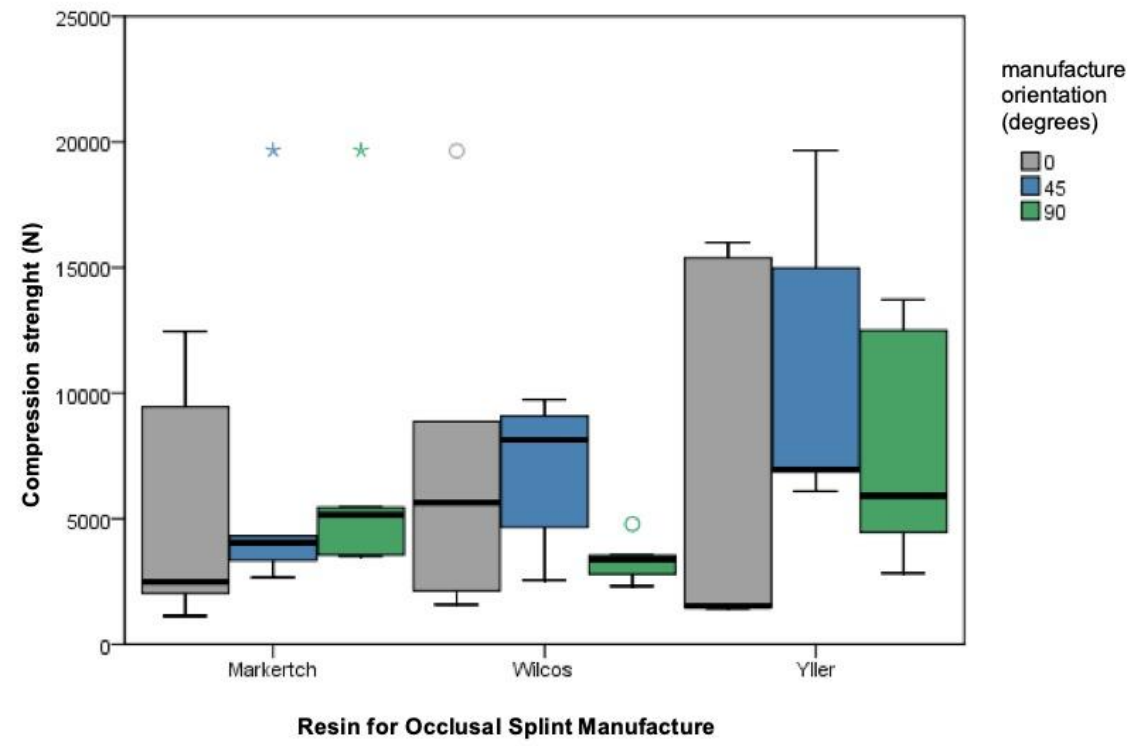

Source: Authors.

Orientation of manufacture had no statistical effect on the compressive strength of resins Prizma Smart Print Bio (Makertech Labs) $(\mathrm{p}=0.292)$ and Resilab Clear (Wilcos) $(\mathrm{p}=0.246)($ Table 1 and Graph 1). On the other hand, orientation affected resin Cosmos Splint (Yller), according to Kruskal-Wallis' test $(\mathrm{p}=0.010)$; according to Dunn's test, the manufacture orientation of 45 degrees obtained larger compressive strength values in comparison with 0 degree and 90 degrees (Table 1 and Graph 1). The 
manufacture orientation of 90 degrees obtained intermediary compressive strength, with no significant difference from other orientations.

\section{Discussion}

Studies show that 3D printed occlusal splints are a safe choice because, compared with conventional and milled splints (Prpic et al., 2019), they are more precise and present good compressive strength, and can be used in the clinical practice (Tahayeri et al., 2018). Other studies also show good precision and accuracy of the digital light processing (DLP) technique in the manufacture of occlusal splints (Brown et al., 2018; Kim et al., 2018; Sherman et al., 2020; Emir et al., 2021). Based on the mentioned results, the present study used the DLP technology as printing method.

Studies show that the orientation of printing influences strength and mechanical properties. Some of these studies show larger strength values for the vertical orientation (Väyrynen et al., 2016; Kebler et al., 2021; Nold et al., 2021). The present study showed that the orientation of 45 degrees of manufacture of occlusal splints with the Cosmos Splint resin increased the compressive strength in comparison with 0 degree; the splints manufactured at 90 degrees showed no significant difference from other orientations in terms of compressive strength. Splints manufactured with Resilab Clear and Prizma Smart Print Bio resins were not affected by angle of orientation in terms of compressive strength.

Studies show that test specimens printed vertically, with the layers positioned perpendicularly to the load vector present enhanced mechanical properties and compressive strength in comparison with those printed horizontally. (Alharbi et al., 2016; Marcel et al., 2020). However, the methods used in the mentioned study are different from the methods used here.

The present study aimed to analyze the compressive strength of occlusal splints manufactured with three different resins in 3D printer in three different manufacture orientations: $0^{\circ}, 45^{\circ}$ and $90^{\circ}$ degrees. Unkovskiy et al. (2018) used a similar method, but the test specimens were designed as bars and the compressive test was done in three points. In the present study, the test specimens were designed as plates on top of a dental model and the compressive test was done along the entire test specimens. Here, results show that the printing orientation can affect the structure of splints manufactured with Cosmos Splint resin; Unkovskiy et al. (2018) results also show that the angle of manufacture influences the strength of the 3D-printed material.

Regarding angle of manufacture, Shim et al. (2020) show that a 90-degree orientation produces the smallest error rates for length and the 45-degree orientation, the largest error rates for thickness; flexural strength increases according to $90<45<0$. Unkovskiy et al. (2021) obtained better mechanical properties with 0 degree.

Rubayo et al. (2020) also obtained better results with 45 and 0 degree, corroborating the present study's findings; however, the 90-degree test specimens required less support and used a smaller amount of material in the manufacturing. Studies that tested flexural strength obtained larger values for the orientation of 45 degrees (Hada et al., 2020; Gao et al., 2021; Grymak et al., 2020).

In the present study and on Hirai et al. (2017) and Vasques, 2018, the occlusal splints were designed with $2 \mathrm{~mm}$ of thickness from the longest cuspid. Kurt et al. (2012) designed the occlusal splints with $3 \mathrm{~mm}$ of thickness to quantify the wearing on different plates.

\section{Conclusion}

The three resins showed the same behavior regarding compressive strength, except for the intragroup effect of orientation with the Cosmos resin, where splints manufactured at 0 degree performed worse than those manufactured at 45 degrees.

More studies using other methodologies, other resins and different angulation orientations are needed to prove the best effectiveness when making plates in 3D Printer. 


\section{References}

A-Alharbi, N., et al. (2016). Effects of build direction on the mechanical properties of 3D-printed complete coverage interim dental restorations. J Prosthet Dent., $115(6), 760-7$.

Berli, C., el al. (2020). Comparing the mechanical properties of pressed, milled, and 3D-printed resins for occlusal devices. J Prosthet Dent, 124(6), 780-786.

Brown, G. B., et al. (2018). Accuracy of 3-dimensional printed dental models reconstructed from digital intraoral impressions. Am J Orthod Dentofacial Orthop., 154(5), 733-739.

De Carvalho, G. A., et al. Polyether ether ketone in protocol bars: Mechanical behavior of three designs. J Int Oral Health., 9, 202-6.

Emir, F. \& Ayyildiz, S. (2021). Accuracy evaluation of complete-arch models manufactured by three different 3D printing technologies: a three-dimensional analysis. J Prosthodont Res., 65(3), 365-370.

Gao, H., et al. (2021). The Effect of Build Orientation on the Dimensional Accuracy of 3D-Printed Mandibular Complete Dentures Manufactured with a Multijet 3D Printer. J Prosthodont.

Grymak, A., et al. (2021). Comparison of hardness and polishability of various occlusal splint materials. J Mech Behav Biomed Mater,115,104270

Hada, T., et al. (2020). Effect of Printing Direction on the Accuracy of 3D-Printed Dentures Using Stereolithography Technology. Materials (Basel), $13(15), 3405$.

Hirai, K., et al. (2017). Evaluation of sleep bruxism with a novel designed occlusal splint. J Prosthodont Res., 61(3), 333-343.

Kebler, A., et al. (2021). In vitro investigation of the influence of printing direction on the flexural strength, flexural modulus and fractographic analysis of 3Dprinted temporary materials. Dent Mater J., 40(3), 641-649.

Kim, S. Y., et al. Precision and trueness of dental models manufactured with different 3-dimensional printing techniques. Am J Orthod Dentofacial Orthop.,153(1),144-153.

Kurt, H., et al. (2012). Two-body wear of occlusal splint materials. J Oral Rehabil., 39(8), 584-90.

Maia, A. P. M. (2014). Avaliação da resistência flexural e rugosidade de resinas acrílicas termopolimerizáveis, empregadas na confecção de placas oclusais, variando técnica e tempo de polimerização. [dissertação]. Brasília: Universidade de Brasília.

Marcel, R., et al. (2020). Accuracy of CAD/CAM-fabricated bite splints: milling vs 3D printing. Clin Oral Invest., 24, 4607-15.

Nold, J., et al. (2021). Does Printing Orientation Matter? In-Vitro Fracture Strength of Temporary Fixed Dental Prostheses after a 1-Year Simulation in the Artificial Mouth. Materials (Basel), 14(2), 259 .

Prpic, V., et al. (2019). A study of the flexural strength and surface hardness of different materials and technologies for occlusal device fabrication. J Prosthet Dent, 121(6), 955-59.

Reymus, M. \& Stawarczyk B. (2020). In vitro study on the influence of postpolymerization and aging on the Martens parameters of 3D-printed occlusal. J Prosthet Dent, 0022-3913(20), 30077-9.

Ribeiro, A. I. A. M., et al. (2014). Análise da resistência flexural de resinas acrílicas termopolimerizáveis utilizadas em placas oclusais. Revista da Faculdade de Odontologia-UPF, 19(1).

Rubayo, D. D., et al. (2020). Influences of build angle on the accuracy, printing time, and material consumption of additively manufactured surgical templates. $J$ Prosthet Dent., 0022-3913(20),30493-5.

Sherman, S. L., et al. (2020). Accuracy of digital light processing printing of 3-dimensional dental models. Am J Orthod Dentofacial Orthop., 157(3), 422-28.

Shim, J. S., et al. (2020). Printing accuracy, mechanical properties, surface characteristics, and microbial adhesion of 3D-printed resins with various printing orientations. J Prosthet Dent.,124(4), 468-75.

Tahayeri, A., et al. (2018). 3D printed versus conventionally cured provisional crown and bridge dental materials. Dent Mater, 34(2), 192-200.

Unkovskiy, A., et al. (2018). Objects build orientation, positioning, and curing influence dimensional accuracy and flexural properties of stereolithographically printed resin. Dent Mater, 34(12), 324-333.

Unkovskiy, A., et al. (2021). Stereolithography vs. Direct Light Processing for Rapid Manufacturing of Complete Denture Bases: An In Vitro Accuracy Analysis. J Clin Med., 10(5), 1070.

Vasques, M. T. (2018). Desenvolvimento de uma técnica de desenho digital e impressão em 3D de placas oclusais e sua aplicabilidade no tratamento de pacientes com disfunção temporomandibular [tese]. São Paulo: Faculdade de Odontologia da Universidade de São Paulo.

Väyrynen, V. O., et al. (2016). The anisotropicity of the flexural properties of an occlusal device material processed by stereolithography. J Prosthet Dent., 116(5), 811-817.

Wendler, M., et al. (2016). Chairside CAD/CAM materials. Part 2: Flexural strength testing. Dent Mater, 33(1), 99-109. 